University of Pennsylvania Carey Law School

Penn Law: Legal Scholarship Repository

Faculty Scholarship at Penn Law

$1-1-2009$

\title{
A System of Excuses: How Criminal Law's Excuse Defenses Do, and Don't, Work Together to Exculpate Blameless (And Only Blameless) Offenders
}

Paul H. Robinson

University of Pennsylvania Carey Law School

Follow this and additional works at: https://scholarship.law.upenn.edu/faculty_scholarship

Part of the Criminal Law Commons, Criminology and Criminal Justice Commons, Law and Society Commons, and the Personality and Social Contexts Commons

\section{Repository Citation}

Robinson, Paul H., "A System of Excuses: How Criminal Law's Excuse Defenses Do, and Don't, Work Together to Exculpate Blameless (And Only Blameless) Offenders" (2009). Faculty Scholarship at Penn Law. 283.

https://scholarship.law.upenn.edu/faculty_scholarship/283

This Article is brought to you for free and open access by Penn Law: Legal Scholarship Repository. It has been accepted for inclusion in Faculty Scholarship at Penn Law by an authorized administrator of Penn Law: Legal Scholarship Repository. For more information, please contact PennlawIR@law.upenn.edu. 


\title{
A SYSTEM OF EXCUSES: HOW CRIMINAL LAW'S EXCUSE DEFENSES DO, AND DON'T, WORK TOGETHER TO EXCULPATE BLAMELESS (AND ONLY BLAMELESS) OFFENDERS
}

\author{
Paul H. Robinson ${ }^{*}$
}

I. What EXCUSES SAY ABOUT CRIMINAL LAW .................................259

II. ARE EXCUSE DEFENSES DISTINCT? ..................................................261

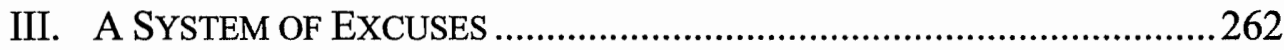

IV. "SYSTEM OF EXCUSES" AS A BASIS FOR CRITIQUE .............................268

This Article looks at excuses as a group. Do excuses represent a coherent conceptual category? Do they have common purposes and internal structures? If so, what, if anything, can be learned from looking at excuses as a group? (As used here, the term "excuses" is meant to refer to general defenses of excuse and does not include the many doctrines of mitigation.)

\section{What EXCUSES SAY ABOUT CRIMINAL LAW}

The subject of excuses is a favorite of mine, in part because of what it says about criminal law. Unlike so many other areas of law, which are driven by ad hoc policy analyses or-worse - ad hoc doctrinal rules without coherent rationales, excuses offer a coherent conceptual structure that organizes a diverse set of legal rules. Excuses exemplify law at its rational best.

I am not so naïve as to think that this is how excuses were consciously constructed - that is, by common law judges thinking in larger systematic terms - but it is the result today. Be it the result of a set of shared intuitions about excuse among common law judges or a result of the systematic approach of the Model Penal Code (MPC) drafters, today there is indeed a "system of excuses." The system has its flaws, but it nonetheless represents something that is quite elegant and highly functional.

Another reason why excuses are such an interesting topic is because of what they say about criminal law's dominant purpose. Even in the heyday

Colin S. Diver Professor of Law, University of Pennsylvania Law School. This Article is based upon the author's Luncheon Address at the 2009 Criminal Law Symposium: Excuses and the Criminal Law, held at Texas Tech University School of Law on April 3, 2009. A video of the original address is available at http://media.law.ttu.edu/Mediasite/Viewer/?peid=a1ac16b1c86b4d77bb77c078 b348c29f. 
of general deterrence, rehabilitation, and incapacitation of the dangerous, when recognizing excuse defenses was commonly inconsistent with these distributive principles, the criminal law nonetheless always kept the doctrines of excuse. Thus, the unbroken recognition of excuse defenses stands as a testament to criminal law's steadfast commitment to desert as at least a central part of its foundational distributive principle.

How does one draw the conclusion that the recognition of excuse defenses is inconsistent with the traditional instrumentalist distributive principles? As argued elsewhere, general deterrence could make great strides in clarifying its deterrent message if it denied acquittals for excuses. ${ }^{1}$ Similarly, incapacitation and rehabilitation of the dangerous similarly could be advanced by denying excuse defenses and taking jurisdiction over such defendants, at least in those cases where the disability causing the excusing condition continues or may reoccur, as is commonly the case with insanity, intoxication from alcoholism or drug addiction, involuntariness from physiological causes, and immaturity.

Finally, excuses are interesting because they lay bare the criminal law's concern for the community's sense of justice. It is hard to look at the standard formulations of excuse defenses without seeing clear and repeated deference to laypersons' shared intuitions of justice. This is so, despite the fact that the legality interests of fair notice and uniform application argue in favor of more objective and specific excuse rules and argue against such deference to the unarticulated complexities of lay intuitions. In formulating excuse defenses, the criminal law typically sacrifices these legality virtues in order to more faithfully capture society's sometimes-complex judgments about justice.

Consider some standard excuse formulations:

Insanity and Involuntary Intoxication: when the actor "lacks substantial capacity either to appreciate its criminality [wrongfulness] or to conform his conduct to the requirements of law"; 2

Duress: when the actor is coerced by a threat that "a person of reasonable firmness in his situation would have been unable to resist"; ${ }^{3}$ and

Mistake as to a Justification: when the actor has a mistaken belief in justifying circumstances that "involves a gross deviation from the standard of care that a reasonable person would observe in the actor's situation.,"

In each instance, the decisionmaker is left to her own intuitions of justice in sorting out whether or not each defense's criteria are satisfied.

1. Paul h. Robinson, Distributive Principles of Criminal law: Who Should Be PUNISHED HOW MUCH?, chs. 4 \& 6 (2008).

2. MODEL PENAL CODE $\S \S 2.08,4.01$ (1962).

3. Id. $\S 2.09$.

4. Id. $\S 2.02(2)(\mathrm{d})$. 


\section{ARE EXCUSE DEFENSES DISTINCT?}

The issue of whether excuse defenses are a distinct conceptual category is, in my own view, now beyond any reasonable dispute. The only people who still resist recognizing the conceptual group of excuses are those who have contorted some aspect of the excuses doctrine so as to muddle the clarity of the category. ${ }^{5}$ For example, if one insists that a mistake as to justification is not really an excuse but rather a justification, it creates some difficulty in sorting out a clear conception of excuses. But, confusion here is a self-inflicted wound. Kent Greenawalt's well known article on the "Perplexing Borders of Justification and Excuse"" is a bit like insisting that a horse was a kind of cow, and then complaining about the confusing variety of cows (this Symposium is convened in Texas). ${ }^{7}$

The central features of excuse defenses may be summarized this way: Conceptually, the defenses perform the same function-exculpating an actor whose conduct may well have violated the objective rules of conduct that the criminal law seeks to announce for future conduct, but who is blameless for his conduct at hand. In the situation at hand, society could not reasonably have expected the actor to have remained law-abiding. Claims of excuse require judgments about the actor and his blameworthiness, not about the act.

On a more practical level, excuse defenses share a common function in that, as a group, they define the triggering conditions for defensive force. The law should allow the use of force to resist an excused aggressor; it should not allow the use of force to assist an excused aggressor. Every organized system of criminal law agrees that these are the proper rules, and it is impossible to implement these rules without recognizing the conceptual group of excuse defenses. Of course, one can reach the right results through hugely complicated and difficult-to-apply rules, such as $\S 3.11(1)$ of the MPC. ${ }^{8}$ The MPC must create a new label and concept of "not privileged" because it has hopelessly muddled its own justification-excuse distinction. ${ }^{9}$ But whatever one does, at the end of the day the rules must rely upon the distinction between excuse and objective justification if the triggering conditions for defensive force are to work properly.

5. See Session II, Panel I: Is There Really a Difference Between Justification and Excuse (Or Did We Academics Make It Up)?, available at http://media.law.ttu.edu/Mediasite/Viewer/?peid=d43efa4cb4 a8466d9b981b9189caba61.

6. Kent Greenawalt, The Perplexing Borders of Justification and Excuse, 84 COLUM. L. REV. 1897 (1984).

7. See generally Paul H. Robinson, Objective Versus Subjective Justification: A Case Study in Function and Form in Constructing a System of Criminal Law Theory, in CRIMINAL LAW CONVERSATIONS 343, 343-53, 361-63 (Paul H. Robinson et al., eds., 2009).

8. Model PENAL CODE $\S 3.11(1)$ (1962).

9. See Paul H. Robinson, A Functional Analysis of Criminal Law, 88 Nw. U. L. REV. 857, 881 (1994). 
One last practical value of recognizing and distinguishing the conceptual category of excuses arises in the context of the legality principle and its demands on statutory drafting. As I have argued elsewhere, the legality principle has quite different purposes and standards depending upon whether it is applied to doctrines that serve to announce ex ante the rules of conduct for the future, or to doctrines that serve to adjudicate ex post a violation of one of those rules. ${ }^{10}$ These distinct goals of fair notice and fair adjudication, respectively, call for different drafting standards for different criminal law doctrines according to which function the doctrine serves. ${ }^{11}$ As a group, excuse defenses serve the latter (ex post) adjudication function, rather than the former, and therefore fall under a different set of drafting standards than would be used for drafting offense prohibitions. ${ }^{12}$ Excuse defenses are applied only by decisionmakers in the criminal justice process (which may include laypersons, but only after they have been given legal instructions) rather than having the general population as their audience, as is the case for conduct prohibitions. ${ }^{13}$ Also affecting the drafting rules for excuses is the fact that they have the luxury of careful and thoughtful deliberation in their application and thus, can tolerate more subjective and complex criteria than would be wise in drafting ex ante rules of conduct. ${ }^{14}$

\section{A SYSTEM OF EXCUSES}

What can we say about the criminal law's "system of excuses"? What insights, if any, can we gain by understanding excuses as a group of interlocking defenses?

As previously noted, excuse defenses share both conceptual and practical features. ${ }^{15}$ They also share a common internal structure of sorts, noted in Figure 1. ${ }^{16}$ Interestingly, the disability excuses-insanity, involuntary intoxication, immaturity, duress, and involuntary conductoperate by distinguishing the defendant from normal people, while the mistake excuses-reasonable mistake of law and reasonable mistake as to a justification-work in what seems to be the opposite way, by showing the defendant to be acting just as others would act. ${ }^{17}$ But in fact, the two kinds

10. Paul H. Robinson, Fair Notice and Fair Adjudication: Two Kinds of Legality, 154 U. PA. L. REV. 335, 337-77 (2005).

11. See id. at 377-78.

12. See id. at $370-72,377$.

13. See id. at $377-78$.

14. See id. at $377-79$.

15. See discussion supra Part II.

16. See Paul H. Robinson, 1 Criminal law Defenses $\S 25$ (b) (West 1984); Paul H. ROBINSON, 2 CRIMINAL LAW DEFENSES $§ 161$ (a) (West 1984); infra note 26.

17. Compare 1 RoBINSON, supra note $16, \S 25$ (West 1984) (definition and internal structure of excuses), and MODEL PENAL CODE (U.L.A.) $\S \S 2.01,2.08,2.09,4.01$ (2001) (general principles of liability and mental diseases or defect), with 2 RoBINSON, supra note $16, \S 181$ (a) (mistake excuses), and MODEL PENAL CODE (U.L.A.) § 2.04 (2001) (ignorance and mistake). 
of excuses have the same agenda. They ask whether we could have reasonably expected the defendants to have remained law-abiding given the situation they faced.

Disability excuses have a common internal structure made up of two elements: a disability requirement and an excusing condition requirement, each of which performs an important independent function. ${ }^{18}$ The disability requirement consists of some objectively confirmable, real-world abnormality. ${ }^{19}$ The excusing condition requirement consists of a particular effect from a disability operating on the actor at the time of his conduct constituting the offense. ${ }^{20}$

The criminal law typically recognizes four different kinds of excusing conditions. ${ }^{21}$ The graphic below shows these in language commonly found in current law. ${ }^{22}$ The first excusing condition consists of the most severe effects. The language is taken from MPC $\S 2.01(2)(d) .{ }^{23}$ The second and third excusing conditions-significant impairments, albeit not so dramatic as those captured by the first condition - track the classic language used in the M'Naghten decision and the many insanity formulations based thereupon. ${ }^{24}$ The fourth excusing condition, somewhat more controversial for some people, focuses upon impairment of control; the language here is from the control prong of the MPC's insanity and involuntary intoxication defenses. $^{25}$

18. See 1 RoBINSON, supra note $16, \S 25(\mathrm{~b})(1)-(2)$.

19. See id. § 25(b)(1).

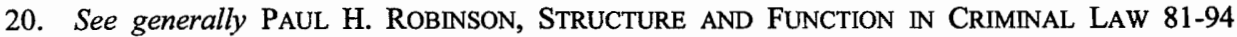
(Oxford 1997) [hereinafter ROBINSON, STRUCTURE AND FUNCTION IN CRIMINAL LAW] (discussing excuses, their general internal structure, and the problem of multiple excuses).

21. See 1 RoBINSON supra note $16, \S 25(\mathrm{~b})(2)$.

22. See infra note 26.

23. Compare 1 ROBINSON, supra note $16, \S 25(\mathrm{~b})(2)$ (discussing excusing conditions), with MODEL PENAL CODE (U.L.A.) § 2.01(2)(d) (2001) (listing actions that do not qualify as voluntary acts).

24. Compare 1 RoBINSON, supra note $16, \S 25$ (b)(2) (discussing excusing conditions), with Wayne R. LaFave, CRIMINAL LAW $\S 7.2($ a)-(c) (4th ed. 2003) (discussing and criticizing the M'Naghten test).

25. Compare 1 RoBINSON, supra note 16, § 25(b)(2) (discussing excusing conditions), with MODEL PENAL CODE $\S \S 2.01(2), 2.08,4.01$ (2001) (voluntary acts, intoxication, and mental diseases or defects). 


\section{Internal Structure of Excuse Defenses}

\begin{tabular}{|c|c|c|}
\hline $\begin{array}{l}\text { Disability } \\
\text { Excuses }\end{array}$ & Disability & $\begin{array}{l}\text { Excusing conditions, in } \\
\text { order of apparent } \\
\text { persuasiveness: } \\
\text { 1. Offense conduct not } \\
\text { product of actor's } \\
\text { determination } \\
\text { 2. Does not accurately } \\
\text { perceive physical } \\
\text { nature or } \\
\text { consequences of } \\
\text { conduct } \\
\text { 3. Does not understand } \\
\text { wrongful or } \\
\text { criminal nature of } \\
\text { conduct } \\
\text { 4. Can't substantially } \\
\text { conform his conduct }\end{array}$ \\
\hline $\begin{array}{l}\text { Mistake } \\
\text { Excuses }\end{array}$ & $\begin{array}{l}\text { Reasonable } \\
\text { Mistake }\end{array}$ & 3 above \\
\hline
\end{tabular}

Figure $1^{26}$

If one of these four excusing conditions exists, then there are reasons to think that society could not have reasonably expected the actor to have remained law-abiding.

Notice that the real work of exculpation is done by the excusing condition, not the disability requirement. It is the disability's effect that renders the defendant blameless, not the disability itself. A person is not excused because he is mentally ill, but rather because his mental illness caused sufficient cognitive or control dysfunction so as to render him blameless for the conduct constituting the offense. ${ }^{27}$

One may wonder: If the real work is done by the excusing condition, why bother having anything else? Rather than the current range of excuses, where each is defined by and distinguished from the others by the disability at issue, why not have one big "disability excuse defense" that lists the excusing conditions that the criminal law now recognizes?

There is good reason for the current system of disability-distinguished excuses: each disability creates its own special set of challenges for

26. See 1 RoBINSON, supra note $16, \S 25(b)$.

27. See id. 
administering the excuse. That is, while the disability requirement serves only a modest role in the substantive operation of the excuse - proving some slim objective confirmation of the internal dysfunction - its primary role is to segregate disability excuses so that each of their special administrative problems can be dealt with effectively. This can be illustrated by considering a few examples.

The intoxication excuse requires a special provision designed to investigate the subject's voluntariness in causing the excusing condition. ${ }^{28}$ Note the language governing to the issue, which is found only in this disability excuse:

Section 2.08. Intoxication.

(4) Intoxication that (a) is not self-induced or (b) is pathological is an affirmative defense if by reason of such intoxication the actor at the time of his conduct lacks substantial capacity either to appreciate its criminality [wrongfulness] or to conform his conduct to the requirements of law.

(5) Definitions....

(b) "self-induced intoxication" means intoxication caused by substances that the actor knowingly introduces into his body, the tendency of which to cause intoxication he knows or ought to know, unless he introduces them pursuant to medical advice or under such circumstances as would afford a defense to a charge of crime;

(c) "pathological intoxication" means intoxication grossly excessive in degree, given the amount of the intoxicant, to which the actor does not know he is susceptible. $^{29}$

Note, by referring back to Figure 1, that the formulation in subsection (4), embodies excusing conditions two through four. ${ }^{30}$

The insanity excuse presents drafters with a different challenge. It requires a special rule, italicized below, addressing the problem of mental illness manifested only by antisocial conduct: ${ }^{31}$

Section 4.01. Mental Disease or Defect Excluding Responsibility.

(1) A person is not responsible for criminal conduct if at the time of such conduct as a result of mental disease or defect he lacks substantial capacity either to appreciate the criminality

28. See Model PenAl Code (U.L.A.) § 2.08 (2001).

29. See id. (emphasis added).

30. See supra note 26 and accompanying text.

31. See MODEL PENAL CODE (U.L.A.) § 4.01 (2001). 
[wrongfuiness] of his conduct or to conform his conduct to the requirements of law.

(2) As used in this Article, the terms "mental disease or defect" do not include an abnormality manifested only by repeated criminal or otherwise anti-social conduct. ${ }^{32}$

Note, by referring back to Figure 1, that the formulation embodies excusing conditions two through four, which is also seen in the involuntary intoxication excuse above. ${ }^{33}$

The duress excuse has its own special problems. It must rely upon the weakest of the excusing conditions-excusing condition four, control impairment-yet shows no confirmable external abnormality. ${ }^{34}$ It presents a case of the toughest sell with the least to show. ${ }^{35}$ The solution is to shift the focus of the defense from the internal, unobservable coercion to the external cause of the coercion. As illustrated in the standard formulation below, standing in for excusing condition four is a requirement that the threat causing the coercion be sufficiently forceful as to justify an excuse at all:

Section 2.09. Duress

(1) It is an affirmative defense that the actor engaged in the conduct charged to constitute an offense because he was coerced to do so by the use of, or a threat to use, unlawful force against his person or the person of another, that a person of reasonable firmness in his situation would have been unable to resist. ${ }^{36}$

The immaturity excuse takes an entirely different approach. In order to avoid the burden of litigation to determine the sufficiency of excusing conditions in the defendant, the modern defense formulation substitutes the defendant's chronological age, creating a presumption of immaturity below a certain value. ${ }^{37}$ While it is true that such a presumption creates errors in both directions, the judicial system gains considerable administrative efficiency as a result of not having to litigate the issue.

32. Id. (emphasis added).

33. See supra note 26 and accompanying text.

34. See MODEL PENAL CODE (U.L.A.) § 2.09 (2001).

35. The absence of an external abnormality makes it difficult, for example, to shift the blame from the defendant to the abnormality.

36. $\S 2.09$ (emphasis added).

37. See Paul Robinson \& Michael T. Cahill, Law Without Justice: Why CRiminal Law DOESN'T GIVE PEOPLE WHAT THEY DESERVE 302 (2006). 
Section 4.10 Immaturity Excluding Criminal Conviction; Transfer of Proceedings to Juvenile Court.

(1) A person shall not be tried for or convicted of an offense if: a) at the time of the conduct charged to constitute the offense he was less than sixteen years of age [in which case the Juvenile Court shall have exclusive jurisdiction]; or

(b) at the time of conduct charged to constitute the offense he was sixteen or seventeen years of age, unless:

(i) the Juvenile Court has no jurisdiction over him, or

(ii) the Juvenile Court has entered an order waiving jurisdiction and consenting to the institution of criminal proceedings against him. $^{38}$

At common law, the presumption of immaturity was rebuttable for a middle age-range. ${ }^{39}$ That is, the government could show that offenders below the upper-level cutoff age were nonetheless sufficiently mature to be held responsible for their conduct. ${ }^{40}$ The more serious danger of modern statutes arises from errors of the reverse sort: a defendant over the chronological cutoff age may, in fact, be too immature to be justly held accountable for his conduct. ${ }^{41}$ The defendant may actually satisfy one of the traditional excusing conditions, yet not have an available excuse defense.

Finally, involuntary conduct-such as that done during sleepwalking, hypnotism, or seizure-ought to be excused. Arguments justifying excuses in these circumstances are often more persuasive than those for other disability excuses. MPC $\S 2.01$, for example, lists these as examples of disabilities produced by excusing condition one. ${ }^{42}$ The drafters think that they have good reason to treat these particular disabilities differently than others. In this instance, the effect of the disability is thought to be so severe-causing a bodily movement that "is not a product of the effort or determination of the actor" - that the drafters feel comfortable requiring only proof of the disability and dispensing with any showing of a resulting excusing condition. ${ }^{43}$ In some ways, this is the reverse of other instances discussed previously. Unlike duress, for example, where the weak disability triggers the need for a dramatic external substitute for the

\footnotetext{
38. MODEL PENAL CODE (U.L.A.) $\$ 4.10$ (2001) (emphasis added).

39. See Robinson, supra note 37 , at 302 .

40. See id.

41. See id. at 238 .

42. See MODEL PENAL CODE (U.L.A.) $\$ 2.01$ (2001).

43. Id.
} 
traditional excusing condition four, here the disability is thought to be so strong in its effect that excusing condition one can be presumed.

Section 2.01. Requirement of Voluntary Act.

(1) A person is not guilty of an offense unless his liability is based on conduct that includes a voluntary act or the omission to perform an act of which he is physically capable.

(2) The following are not voluntary acts within the meaning of this Section:

(a) a reflex or convulsion;

(b) a bodily movement during unconsciousness or sleep;

(c) conduct during hypnosis or resulting from hypnotic suggestion;

(d) a bodily movement that otherwise is not a product of the effort or determination of the actor, either conscious or habitual. ${ }^{44}$

This Article, up to this point, has been a quick sketch of our "system of excuses"- - of how and why excuse defenses are similar and different. This kind of conceptual clarity has the usual theoretical and practical benefits, especially for criminal law theorists, code drafters, and judges who must resolve drafting ambiguities. ${ }^{45}$ By focusing on the larger agenda of excuse defenses, drafters can better tailor and judges can better interpret excuse formulations to more effectively fulfill their function.

\section{IV. "SYSTEM OF EXCUSES" AS A BASIS FOR CRITIQUE}

Conceptualizing excuses as a "system" not only brings this conceptual clarity, with its theoretical and practical benefits, but also can serve as a valuable point of critique. Here are three quick examples.

Once one appreciates the parallel function of excuse defenses, it is easier to see the impropriety of different excuse formulations that adopt different excusing conditions for no apparent reason. For example, jurisdictions might disagree about whether to recognize excusing condition four (control impairment), but once the jurisdiction makes the decision, the parallel function of disability excuses, such as insanity and involuntary intoxication, suggests that within such a jurisdiction, they should be treated uniformly. Once one appreciates the analogous purpose and structure of the two defenses, it seems quite odd to see a jurisdiction adopt different excusing conditions for the two. Below are conflicting Alabama statutes that recognize a control impairment for an involuntary intoxication excuse,

44. Id. (emphasis added).

45. See RoBINSON, STRUCTURE AND FUNCTION IN CRIMINAL LAW, supra note 20; see also supra Part III (explaining how a system view of excuses could be structured to improve the function of excuses. 
but deny it as the basis for an insanity excuse. ${ }^{46}$ Alabama is by no means alone in having these conflicts as part of its criminal code. ${ }^{47}$

\section{ASYMMETRICAL EXCUSING CONDITIONS}

Alabama § 13A-3-1. Mental disease or defect.

(a) It is an affirmative defense to a prosecution for any crime that, at the time of the commission of the acts constituting the offense, the defendant, as a result of severe mental disease or defect, was unable to appreciate the nature and quality or wrongfulness of his acts. ${ }^{48}$

Alabama § 13A-3-2. Intoxication.

(c) Involuntary intoxication is a defense to prosecution if as a result the actor lacks capacity either to appreciate the criminality of his conduct or to conform his conduct to the requirements of law. ${ }^{49}$

If a control impairment is enough to excuse the defendant when it is the result of involuntary intoxication, why would the same impairment be insufficient to excuse the defendant when it results from mental illness?

One can find the same asymmetry in reverse in other jurisdictions. For example, Georgia allows a control impairment to provide a defense if it results from mental illness, but denies it as a defense if it results from involuntary intoxication. ${ }^{50}$

\section{ASYMMETRICAL EXCUSING CONDITIONS}

Georgia $\S 16-3-2$. Mental capacity.

A person shall not be found guilty of a crime if, at the time of the act, omission, or negligence constituting the crime, the person did not have mental capacity to distinguish between right and wrong in relation to such act, omission, or negligence. ${ }^{51}$

Georgia § 16-3-3. Delusional compulsion.

A person shall not be found guilty of a crime when, at the time of the act, omission, or negligence constituting the crime, the person, because of mental disease, injury, or congenital deficiency, acted as he did because of a delusional compulsion as to such act which overmastered his will to resist committing the crime. ${ }^{52}$

46. See infra notes $48-49$.

47. See infra notes 51-53.

48. ALA. CODE § 13A-3-1(a) (1977) (emphasis added).

49. Id. § 13A-3-2(c) (emphasis added).

50. See infra notes 51-53.

51. GA. CODE ANN. § 16-3-2 (1968) (emphasis added).

52. Id. $\S 16-3-3$ (emphasis added). 
Georgia § 16-3-4. Intoxication.

(a) A person shall not be found guilty of a crime when, at the time of the act, omission, or negligence constituting the crime, the person, because of involuntary intoxication, did not have sufficient mental capacity to distinguish between right and wrong in relation to such act. $^{53}$

Once one thinks of excuses as a "system" of interlocking defenses serving analogous functions toward the same larger goal, it may be quite a bit easier to spot the irrationality of these sorts of asymmetries.

Here is a second example of the critical power of a "system" view of excuses: once one sees excuses as working together to perform the larger purpose of exculpating blameworthy (and only blameworthy) offenders, one is more likely to notice gaps in the system. Indeed, without the notion of an excuse "system," there can be no notion of a "gap" in the system.

Consider the case, for example, of overwhelming coercion arising from the force of natural circumstances. If the same level of coercion coming from a person renders the defendant blameless, it seems hard to see why it should not have the same effect whether coming from a human or a non-human source. Yet the duress defense is formulated too narrowly to allow an excuse for coercion from a non-human source. A defense for "Duress of Circumstances" could fill the gap if drafted in the following manner: "It is an affirmative defense that the actor engaged in the conduct charged to constitute an offense because he was coerced to do so by the force of circumstances threatening his person or the person of another, which a person of reasonable firmness in his situation would have been unable to resist." Efficient drafting, however, would probably avoid the creation of a new excuse like this example, but instead would broaden the language of the existing duress defense to include the force of circumstances.

Consider one last example of the kind of failures that an insensitivity of the "system" view of excuses invites: $\S 2.01(2)$ of the MPC's involuntary conduct excuse, quoted previously. ${ }^{54}$ If the drafters had thought of disability excuse formulations in terms of an independent disability requirement and an excusing condition requirement, each serving an independent function, they might not have so easily dispensed with proof of an excusing condition in their formulation--an omission that turns out to be quite problematic.

There seems to be little difficulty with MPC $\S 2.01$ (2)(d) giving an excuse when a defendant's bodily movement constituting the offense "is not a product of the effort or determination of the actor." ${ }^{, 55}$ This simply

53. Id. § 16-3-4 (emphasis added).

54. See supra note 44 and accompanying text.

55. MODEL PENAL CODE (U.L.A.) § 2.01(2)(d) (2001). 
requires proof of excusing condition one. The drafters kept the excusing condition and only dispensed with the disability requirement, which is less important-as discussed previously. ${ }^{56}$

The problem arises with subsections (2)(a), (2)(b), and (2)(c), where the drafters require only proof of a disability - seizure, sleepwalking, or hypnotism - and drop the requirement of proof of an excusing condition resulting from such a disability. ${ }^{57}$ Medical science confirms that the disabilities listed could cause the severe dysfunction described in subsection (2)(d) (excusing condition one), but these disabilities also might cause a much lower level of dysfunction and impairment, more in the range of excusing conditions two, three, or four. ${ }^{58}$ Indeed, they might even cause a level of dysfunction and impairment considerably less than any of these. In other words, these disabilities may or may not properly qualify a defendant for an excuse. The determination of when to give an excuse requires an examination of the extent of dysfunction and impairment, as is standard in other disability excuses, yet the Model Code's formulation dispenses with this critical examination.

One could construct an excuse that would provide a proper defense for these and other such disabilities. It might look something like the following, an excuse of "impaired consciousness":

\section{Impaired Consciousness}

A person is not responsible for criminal conduct if at the time of such conduct as a result of:

(a) a bodily movement during unconsciousness or sleep;

(b) conduct from hypnosis or resulting from hypnotic suggestion; or

(c) any other physiologically confirmable abnormal state, he lacks substantial capacity either to appreciate the criminality [wrongfulness] of his conduct or to conform his conduct to the requirements of law.

Indeed, this would be a valuable excuse to have as part of one's system, for it is the only means by which one can deal with the wide variety of miscellaneous physiological abnormalities that can cause excusing conditions that can render an actor blameless. The defense would serve as the excuse system's catch-all provision.

My larger point in this lecture is to suggest that there is real conceptual and practical value in recognizing excuses as a set of doctrines that work together for common purposes and have common features, and that thinking

56. See supra notes $42-43$.

57. MODEL PENAL CODE (U.L.A.) § 2.01(2)(a)-(c) (2001).

58. See generally Deborah W. Denno, A Mind to Blame: New Views on Involuntary Acts, 21 BEHAV. SCI. \& LAW 601 (2003) (criticizing the forced voluntary/involuntary dichotomy in the adversarial legal system because the science does not support these binary distinctions). 
[Vol. 42:259

about excuses as an interlocking "system" of defenses can improve both our ability to draft effective defense formulations and our ability to discover their flaws. 